\title{
Cardiac metastasis from yolk sac tumor: case report and review
}

\author{
Maria Carmo Pereira Nunes ${ }^{1 *}$, Daniel Ribeiro Moreira ${ }^{2}$ and Teresa Cristina Abreu Ferrari ${ }^{1}$
}

\begin{abstract}
Cardiac metastasis of germ cell tumors is extremely rare, particularly in females. We report a case of a 26 -year-old previously healthy woman who presented with a 5-month history of abdominal pain, weight loss, fever, generalized lymphadenopathy, and acanthosis nigricans. Biopsy of cervical lymph nodes revealed a poorly differentiated neoplasm. Immunohistochemical staining was positive for alpha-fetoprotein suggesting the diagnosis of a germ cell tumor. During the investigation, the patient developed heart failure and a mass attached to the right ventricle was detected by the echocardiogram. In a few days, she developed multiple organ failure and died. Post-mortem examination revealed a malignant mixed germ cell tumor of the right ovary with extensive hematogenic and lymphatic dissemination, a polypoid mass attached to the right ventricle, emboli in the endocardial and epicardial vessels, and infiltration surrounding the coronary arteries. To the best of our knowledge this is the third report of grossly visible heart metastases from a yolk sac tumor in a female patient. A summary of all published cases of germ cell tumors with cardiac metastasis over the last 20 years is also presented.
\end{abstract}

Keywords: Cardiac metastasis, Germ cell tumors, Yolk sac tumors, Right ventricular mass

\section{Background}

Ovarian germ cell neoplasm includes tumors with multiple histological patterns, and variable biologic behaviors [1]. These tumors grow rapidly, are usually unilateral and confined to one ovary in two thirds of the cases, and predominate in girls and young women. Mixed germ cell tumors consist of two or more admixed types of ovarian germ cell neoplasms and account for $5.3 \%$ of all malignant ovarian germ cell tumors [2]. Components of dysgerminoma mixed with endodermal sinus tumor (also called yolk sac tumors) are found most commonly. As a highly malignant neoplasm, yolk sac tumors metastasize at an early stage as well invade the surrounding structures and organs [1,3-6].

Although cardiac metastases can arise from different cancers, they are more frequently associated with carcinoma of the lung, breast and esophagus (due to the higher prevalence of these tumors), hematological malignancies including lymphoma and leukemia, and malignant melanoma, which shows the highest affinity to metastasize to the heart [4]. Cardiac metastasis of germ

\footnotetext{
*Correspondence: mcarmo@waymail.com.br

'Department of Internal Medicine, School of Medicine of the Federal University of Minas Gerais, Av. Professor Alfredo Balena, 190, Santa Efigênia, Belo Horizonte, MG 30130 100, Brazil

Full list of author information is available at the end of the article
}

cell tumors is extremely rare, particularly in the female gender. We hereby report a case of a 26-year-old woman with mixed germ cell tumor of the right ovary who presented with widespread metastases including to the right ventricle. Post-mortem examination also showed neoplastic emboli in the endocardial and epicardial vessels and infiltration surrounding the coronary arteries.

\section{Case presentation}

A 26-year-old previously health woman presented with a 5-month history of abdominal pain, weight loss, fever, generalized lymphadenopathy, and acanthosis nigricans. Except for anemia (hemoglobin $11.1 \mathrm{~g} / \mathrm{dl}$ ), blood counts were within the normal ranges. Serological tests for human immunodeficiency virus (HIV), hepatitis viruses, syphilis, toxoplasmosis and cytomegalovirus were negative. Blood chemistry was unremarkable, and blood and urine cultures were negative. Thoracic, abdominal and pelvic computed tomography (CT) showed extensive lymphadenopathy and a solid mass with ill-defined borders near the uterus. The ovaries were not seen. Biopsy of cervical lymph nodes revealed a poorly differentiated neoplasm. Immunohistochemical staining was positive for alpha-fetoprotein suggesting the diagnosis of a germ 
cell tumor. During the investigation, the patient developed heart failure. A transthoracic echocardiography showed right ventricular (RV) dilatation, pericardial effusion, and a mobile mass attached to the endocardial surface of the apex of the RV (Figure 1, panel A). In the following days, she developed multiple organ failure and died before she could be subjected to any type of anticancer treatment. Post-mortem examination revealed a malignant mixed germ cell tumor of the right ovary with predominance of endodermal sinus (yolk sac) tumor elements, and extensive hematogenic and lymphatic dissemination to the lungs, kidneys, liver, intestines, uterine tube, mediastinum, and thyroid gland. A polypoid mass was found attached to the apex of the RV (Figure 1, panels B and C). Neoplastic emboli in the endocardial and epicardial vessels, and infiltration surrounding the coronary arteries were also detected (Figure 1, panel D).

The guardian of the patient provided written informed consent in accordance with the Declaration of Helsinki.

\section{Conclusions}

Intracardiac metastasis is an extremely rare manifestation of germ cell tumors. It occurs by hematogenous spread, direct invasion from neighboring chest tumors or through the pericardial space, usually to the right side of the heart [3-6]. In our case, the neoplastic cells probably reached the heart hematogenously, through the inferior vena cava. Although there were mediastinal metastases, they did not present any continuity with the cardiac lesions.

In a review of the cases of germ cell tumors with cardiac metastasis published over the last 20 years (Table 1 ) [7-24] we found 17 cases: 16 of them were male with testicular seminoma or nonseminomatous germ cell tumor, and only one case of a yolk sac tumor was reported in a female child of 18 months old. In 11 of these reported cases, the metastasis was located in the right-side of the heart; in four, in a left-side chamber; and in two, in the pericardium. Five of the 17 patients

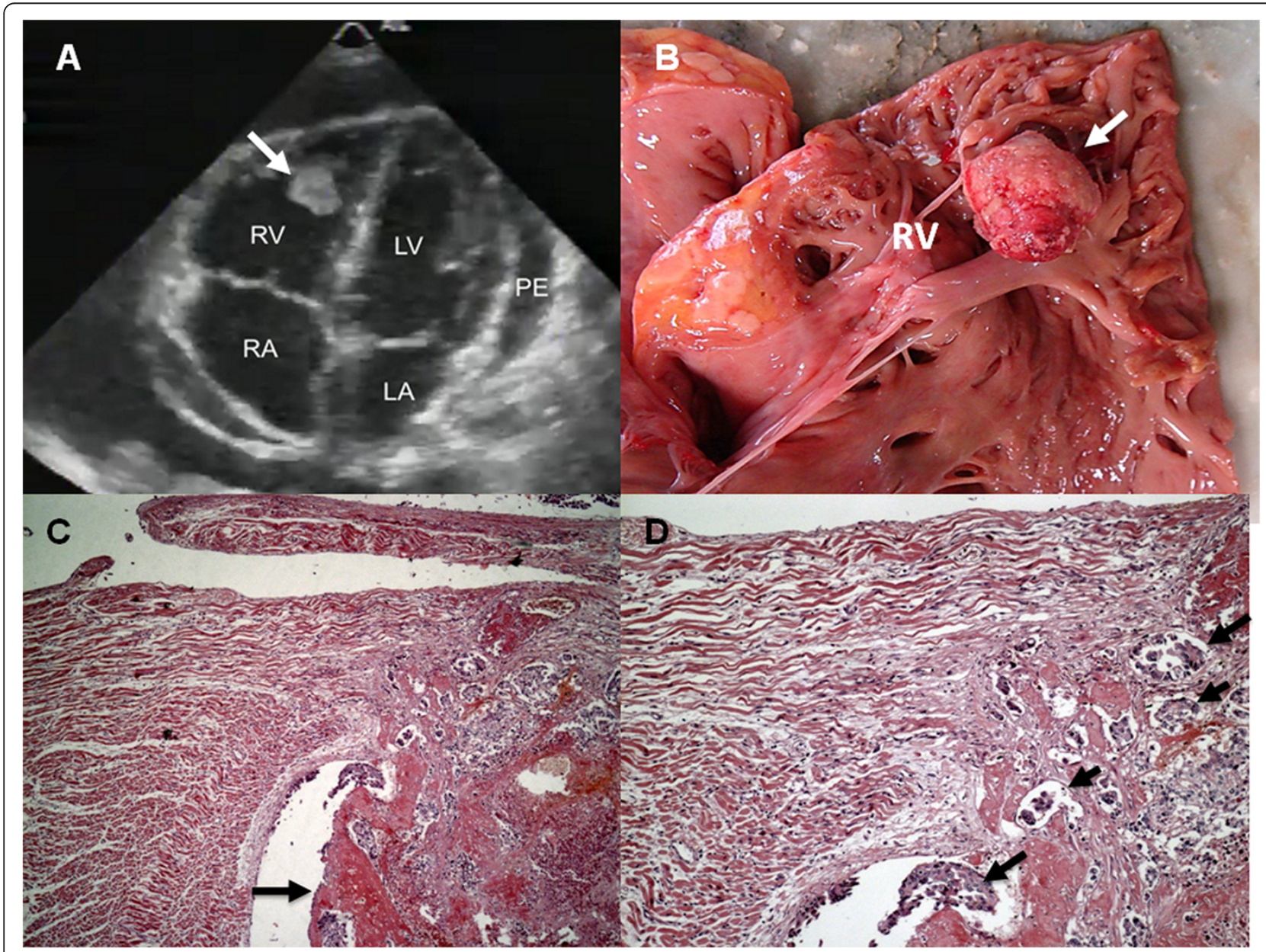

Figure 1 Cardiac involvement by the tumor. A: Image from transthoracic echocardiogram showing a mass attached to the apex of the right ventricle with a pericardial effusion (white arrow). $R V=$ right ventricle; $R A=$ right atrium; $L V=$ left ventricle; $L A=$ left atrium; $P E=$ pericardial effusion. $\mathbf{B}$ : Photography derived from the autopsy showing opened right ventricle with a mass attached to the endocardial surface of the right ventricle (white arrow). RV $=$ right ventricle. C: Polypoid cardiac mass (× 250) (black arrow). D: Emboli of neoplastic cells in myocardial and endocardial vessels ( $\times 400)($ black arrows). 
Table 1 Review of documented cases of germ cell tumors with intracardiac involvement

\begin{tabular}{llllll}
\hline $\begin{array}{l}\text { Reference } \\
\text { (Author/year) }\end{array}$ & $\begin{array}{l}\text { Gender/ } \\
\text { age } \\
\text { (years) }\end{array}$ & $\begin{array}{l}\text { Primary tumor } \\
\text { (Histological type) }\end{array}$ & $\begin{array}{l}\text { Time between } \\
\text { diagnosis of } \\
\text { primary tumor } \\
\text { and cardiac } \\
\text { metastasis }\end{array}$ & $\begin{array}{l}\text { Clinical manifestation of } \\
\text { cardiac metastasis }\end{array}$ & $\begin{array}{l}\text { Management/ } \\
\text { Outcome }\end{array}$ \\
\hline
\end{tabular}

\begin{tabular}{|c|c|c|c|c|}
\hline $\begin{array}{l}\text { Savarese et al., } \\
1995[7]\end{array}$ & Male/25 & $\begin{array}{l}\text { Testicular nonseminomatous } \\
\text { mixed germ cell tumor }\end{array}$ & $\begin{array}{l}\text { At diagnosis of } \\
\text { the primary } \\
\text { tumor }\end{array}$ & $\begin{array}{l}\text { Right atrium } \\
\text { extending to } \\
\text { right ventricle }\end{array}$ \\
\hline $\begin{array}{l}\text { Bath et al., } \\
1997 \text { [9] }\end{array}$ & $\begin{array}{l}\text { Female/ } \\
1.5\end{array}$ & Yolk sac tumor & $\begin{array}{l}\text { At diagnosis of } \\
\text { the primary } \\
\text { tumor }\end{array}$ & $\begin{array}{l}\text { Intrapericardium } \\
\text { infiltrating the } \\
\text { right atrium }\end{array}$ \\
\hline
\end{tabular}

Vohr et al 1999 [10]

Low et al.,

1999 [11]

Deck et al.,

$2000[12]$

Singh et al 2000 [13]

Male/27 Yolk sac tumor

Testicular embryona carcinoma with extensive vascular emboli

Male/20 Testicular nonseminomatous 3 years mixed germ cell tumor

At diagnosis of Right atrium the primary tumor

Severe low back and swelling of the left, Surgical resection

$$
4 \text { months Left atrium }
$$

Alaeddini et al. 2001 [14]

Stefka J., 2003 [15]

\section{Male/40}

Testicular mixed nonseminomatous germ cell tumor (metastatic sarcomatoid germ cell tumor)

Weinberg et al

Male/26 2004 [16]

May et al. 2006 [17]

Male/42 Testicular germ cell tumor

Testicular seminoma and smaller amounts of choriocarcinoma, teratoma, yolk sac, and embryonal carcinomas

$\begin{array}{lll} & & \\ \text { Fujimura et al., [18] } & \text { Male/30 } & \text { Testicular seminoma } \\ \text { Liu et al., } & \text { Male/51 } & \text { Testicular nonseminomatous } \\ 2007 \text { [19] } & & \text { germ cell tumor }\end{array}$

At diagnosis of the primary tumor

At diagnosis of Left atrium the primary tumor

4 years cava

Right atrium extending from the superior vena cava

Right atrium that prolapsed through the tricuspid valve into the right ventricle

Right atrium protruding through the tricuspid valve up to the pulmonary valve

At diagnosis of Left ventricle the primary sac, embryonal carcinoma sac, embryonal carcinoma
seminoma, and teratoma)

tumor

\section{2 years \\ Pericardium}

$\begin{array}{ll}\text { At diagnosis of } & \text { Right atrium } \\ \text { the primary } & \text { extending into }\end{array}$ tumor epigastric pain, painless testicle, and a 20-pound weight loss

Lethargy, anorexia, tachypnea, cardiomegaly on chest $x$-ray and pericardial effusion on echocardiogram

Syncope

Respiratory distress and

stroke

Breathlessness for several weeks before hospital admission and dilated veins over the upper thorax

A new systolic ejection cardiac murmur

Acute lower limb ischemia

Right-sided heart failure

Left-sided thoracic pain, shortness of breath on exertion, painless swelling of the left testicle, and a 20-pound weight loss

Shortness of breath

Progressive shortness of

2 years without evidence of recurrence

Chemotherapy; remission 1 year following completion of treatment

Surgical resection; 1 year after cardiac surgery, a retroperitonea metastasis was detected;

Patient died 6 months after initial diagnosis

Tricuspid valve replacement; 1 year without evidence of recurrence

Emergency excision of the tumor; patient died 5 weeks after initial presentation

Surgical resection with tricuspid valve replacement.

Surgical resection

Chemotherapy; patient died 6 months after initial diagnosis

Surgical resection; stable for 12 months after surgery

Sudden death

Surgical resection; breath and pleuritic chest 17 months from pain initial presentation clinically free of disease. the right ventricle
and pulmonary arteries bilaterally 
Table 1 Review of documented cases of germ cell tumors with intracardiac involvement (Continued)

\begin{tabular}{|c|c|c|c|c|c|c|}
\hline $\begin{array}{l}\text { Avasthi et al., } \\
2008[20]\end{array}$ & Male/21 & $\begin{array}{l}\text { Testicular nonseminomatous } \\
\text { mixed germ cell tumor }\end{array}$ & 2 years & Left atrium & Shock & $\begin{array}{l}\text { Died within an hour } \\
\text { of admission }\end{array}$ \\
\hline $\begin{array}{l}\text { Taghavi et al., } \\
2010 \text { [21] }\end{array}$ & Male/32 & $\begin{array}{l}\text { Testicular nonseminomatous } \\
\text { germ cell tumor }\end{array}$ & $\begin{array}{l}\text { At diagnosis of } \\
\text { the primary } \\
\text { tumor }\end{array}$ & $\begin{array}{l}\text { Right ventricle } \\
\text { with an extension } \\
\text { into the right } \\
\text { atrium }\end{array}$ & $\begin{array}{l}\text { Emergency department } \\
\text { very short breath }\end{array}$ & $\begin{array}{l}\text { Chemotherapy; CT- } \\
\text { scan at 12-month } \\
\text { follow-up revealed } \\
\text { complete resolution } \\
\text { of the cardiac lesion }\end{array}$ \\
\hline $\begin{array}{l}\text { Gursu et al., } \\
2011 \text { [22] }\end{array}$ & Male/17 & $\begin{array}{l}\text { Testicular nonseminomatous } \\
\text { germ cell tumor }\end{array}$ & $\begin{array}{l}\text { At diagnosis of } \\
\text { the primary } \\
\text { tumor }\end{array}$ & Right atrium & Right-sided heart failure & $\begin{array}{l}\text { Surgical excision; } \\
\text { stable for } 6 \text { months } \\
\text { after surgery }\end{array}$ \\
\hline $\begin{array}{l}\text { Achouh et al., } \\
2012 \text { [23] }\end{array}$ & Male/32 & $\begin{array}{l}\text { Testicular mixed germ cell } \\
\text { tumor }\end{array}$ & Around 1 year & Right atrium & $\begin{array}{l}\text { Thrombosis of superior } \\
\text { vena cava and right atrium } \\
\text { mass }\end{array}$ & Not available \\
\hline $\begin{array}{l}\text { Jonjev et al., } \\
2012 \text { [24] }\end{array}$ & Male/24 & $\begin{array}{l}\text { Testicular mixed germ cell } \\
\text { tumor (yolk sac malignant } \\
\text { cells with large and } \\
\text { pleomorphic nuclei } \\
\text { scattered with islands of } \\
\text { cartilage) }\end{array}$ & 2 years & Right atrium & $\begin{array}{l}\text { Acute right-sided heart } \\
\text { failure }\end{array}$ & $\begin{array}{l}\text { Surgical excision; } \\
\text { stable for } 6 \text { months } \\
\text { after surgery }\end{array}$ \\
\hline Our case/2012 & $\begin{array}{l}\text { Female/ } \\
26\end{array}$ & $\begin{array}{l}\text { Mixed germ cell tumor of } \\
\text { the right ovary with } \\
\text { predominance of } \\
\text { endodermal sinus (yolk sac) } \\
\text { tumor elements }\end{array}$ & $\begin{array}{l}\text { Metastasis } \\
\text { diagnosis } \\
\text { before the } \\
\text { identification of } \\
\text { the primary } \\
\text { tumor }\end{array}$ & Right ventricle & $\begin{array}{l}\text { Abdominal pain, weight } \\
\text { loss, fever, generalized } \\
\text { lymphadenopathy, and } \\
\text { acanthosis nigricans }\end{array}$ & $\begin{array}{l}\text { Died before } \\
\text { chemotherapy }\end{array}$ \\
\hline
\end{tabular}

died early in the chemotherapy treatment, and in eight, the disease was in remission at the time of the publication. Surgical resection of the metastasis followed by chemotherapy was the therapeutic approach performed in most cases.

A more extensive review, without limiting period of time, revealed just another case of germ cell tumor with cardiac metastasis in female. It was a primary chorion carcinoma of the right ovary with metastases to the left atrium in a 35-year-old woman, who presented with multiple metastases and died of respiratory failure, three months after the diagnosis [25].

A high level of suspicion is needed to establish the diagnosis of cardiac tumors. Frequently, the tumor is found incidentally during evaluation for a seemingly unrelated problem. Cardiac metastases often occur late in the course of a malignant disease and produce clinical symptoms in only about $10 \%$ of the affected patients [4-6]. Site, size, and tendency to cause embolism determine the clinical findings. In symptomatic patients, a mass is commonly detected by imaging methods, especially echocardiography. As the symptoms may mimic other cardiac conditions, the clinical challenge is to consider the possibility of a cardiac tumor; so that the appropriate diagnostic test can be conducted. Specific signs and symptoms are generally determined by the location of the tumor in the heart and not by the histological type [4-6]. Cardiac tamponade is one of the earliest and most frequent symptoms. Cardiac malignant disease may also cause arrhythmias and heart failure. The classic triad includes: symptoms resulting from intracardiac obstruction, signs of systemic embolization, and systemic symptoms $[5,6]$.

Recommended treatment for patients with advanced malignant ovarian germ cell tumors and non-dysgerminoma histology is maximal cytoreduction followed by platinumbased combination chemotherapy [26,27]. Emergency surgical resection of intra-cardiac metastases has been recommended in the compromised patient and can be lifesaving [21]. New technical modalities (e.g., modern echocardiography, computed tomography, magnetic resonance imaging) provide noninvasive visualization of the intracardiac mass, which assists in designing the surgical approach not only to eliminate tumor tissue, but also to restore or maintain the hemodynamic status [14,24]. Most patients treated aggressively will be long-term survivors even if they have advanced disease. However, despite the sensitivity of ovarian germ cell tumors to platinum-based chemotherapy, tumor volume still remains one of the most important prognostic factors for outcome, as evident in the case presented, where outcome was poor due to highly disseminated metastatic disease.

To the best of our knowledge this is the third report of grossly visible heart metastases from a yolk sac tumor in a female patient.

\section{Consent}

Written informed consent was obtained from the mother of the patient for publication of this case report and any accompanying images. 


\section{Competing interests}

The authors declare that they have no competing interests.

\section{Authors' contributions}

All authors have made important contributions to the manuscript and have approved this final version.

\section{Author details}

'Department of Internal Medicine, School of Medicine of the Federal University of Minas Gerais, Av. Professor Alfredo Balena, 190, Santa Efigênia, Belo Horizonte, MG 30130 100, Brazil. ${ }^{2}$ Department of Patology and Legal Medicine, School of Medicine of the Federal University of Minas Gerais, Belo Horizonte, MG, Brazil.

Received: 14 January 2013 Accepted: 13 April 2013

Published: 30 April 2013

\section{References}

1. Gershenson DM: Management of ovarian germ cell tumors. J Clin Oncol 2007, 25:2938-2943.

2. Smith HO, Berwick M, Verschraegen CF, Wiggins C, Lansing L, Muller CY, Qualls CR: Incidence and survival rates for female malignant germ cell tumors. Obstet Gynecol 2006, 107:1075-1085.

3. Mahdi H, Swensen RE, Hanna R, Kumar S, Ali-Fehmi R, Semaan A, Tamimi H, Morris RT, Munkarah AR: Prognostic impact of lymphadenectomy in clinically early stage malignant germ cell tumour of the ovary. Br J Cancer 2011, 105:493-497.

4. Reynen K, Kockeritz U, Strasser RH: Metastases to the heart. Ann Oncol 2004, 15:375-381.

5. Butany J, Nair V, Naseemuddin A, Nair GM, Catton C, Yau T: Cardiac tumours: Diagnosis and management. Lancet Oncol 2005, 6:219-228.

6. Neragi-Miandoab S, Kim J, Vlahakes GJ: Malignant tumours of the heart: a review of tumour type, diagnosis and therapy. Clin Oncol (R Coll Radiol) 2007, 19:748-756.

7. Savarese DM, Rohrer MJ, Pezzella AT, Davidoff A, Fraire AE, Menon M: Successful management of intracardiac extension of tumor thrombus in a patient with advanced nonseminomatous germ cell testicular cancer. Urology 1995, 46:883-887.

8. Sarjeant JM, Butany J, Cusimano RJ: Cancer of the heart: epidemiology and management of primary tumors and metastases. Am J CardiovasC Drugs 2003, 3:407-421.

9. Bath LE, Walayat M, Mankad P, Godman MJ, Wallace WH: Stage iv malignant intrapericardial germ cell tumor: a case report. Pediatr Hematol Oncol 1997, 14:451-455.

10. Vohra A, Saiz E, Davila E, Burkle J: Metastatic germ cell tumor to the heart presenting with syncope. Clin Cardiol 1999, 22:429-433.

11. Low LL, Yip SK, Ang PC, Cheah FK: Testicular carcinoma with superior vena cava obstruction and atrial extension. Urology 1999, 54:363-364.

12. Deck AJ, True LD, Higano CS: Tricuspid valve metastasis from testicular carcinoma: a case report and review of the literature. Urology 2000, 56:330.

13. Singh A, Jenkins DP, Dahdal M, Dhar S, Ratnatunga CP: Recurrent arterial embolization from a metastatic germ cell tumor invading the left atrium. Ann Thorac Surg 2000, 70:2155-2156.

14. Alaeddini J, Chandra M, Tang J, Ilercil A, Shirani J: Cardiac metastasis from testicular mixed germ cell tumor. Clin Cardiol 2001, 24:689.

15. Stefka J, Cleveland JC, Lucia MS, Singh M: Sarcomatoid intracardiac metastasis of a testicular germ cell tumor closely resembling primary cardiac sarcoma. Hum Pathol 2003, 34:1074-1077.

16. Weinberg NM, Zwas DR, Owen AN, Zangrilli JG, Van Tassell P: Left ventricular intracardiac metastatic germ cell tumor presenting with hemorrhagic cerebrovascular event. J Am Soc Echocardiogr 2004, 17:1080-1083.

17. May M, Finkbeiner Y, Gunia S, Seehafer M, Knorig J, Hetzer R: Metastasizing testicular germ-cell tumor with infiltration of the right heart: Indication for primary metastasectomy. Hear Vessel 2006, 21:63-65.

18. Fujimura T, Minowada S, Kishi H, Hamasaki K, Saito K, Kitamura T: Acute pericarditis as a result of unusual metastasis of the visceral pleura in a patient with testicular seminoma. Int J Urol 2006, 13:653-654.

19. Liu JX, Eftimie B, Mortimer J: Intracardiac metastasis of germ cell tumor complicated by pulmonary hypertension and thrombocytopenia. J Clin Oncol 2007, 25:3547-3549.
20. Avasthi R, Chaudhary SC, Mohanty D, Mishra K: Testicular mixed germ cell tumor metastasizing to heart. J Assoc Physicians India 2008, 56:812-815.

21. Taghavi F, Markar S, Williams M, Large S: Intra-cardiac metastasis from testicular non-seminoma germ cell tumour; to resect or not to resect. Interact Cardiovasc Thorac Surg 2010, 11:843-845.

22. Gursu O, Isbir S, Ak K, Ozben B, Turkoz HK, Dal D, Arsan S: Testicular germ cell tumor metastatic to the right atrium. J Card Surg 2011, 26:276-279.

23. Achouh P, Grinda JM, Emmerich J, Fabiani JN: Right atrial metastasis of a testicular cancer. Eur J Cardiothorac Surg. 2012, 41:712.

24. Jonjev ZS, Rajic J, Majin M, Donat D: Intracardiac metastasis from germ cell testicular tumor. Herz 2012, 37:709-711.

25. Hepp A, Larbig D, Bader H: Left atrial metastasis of chorion carcinoma, presenting as mitral stenosis. Br Heart J 1977, 39:1154-1156.

26. Williams SD, Blessing JA, Moore DH, Homesley HD, Adcock L: Cisplatin, vinblastine, and bleomycin in advanced and recurrent ovarian germ-cell tumors. A trial of the gynecologic oncology group. Ann Intern Med 1989, 111:22-27.

27. Gershenson DM, Morris M, Cangir A, Kavanagh JJ, Stringer CA, Edwards CL, Silva EG, Wharton JT: Treatment of malignant germ cell tumors of the ovary with bleomycin, etoposide, and cisplatin. J Clin Oncol 1990, 8:715-720.

doi:10.1186/2162-3619-2-13

Cite this article as: Nunes et al:: Cardiac metastasis from yolk sac tumor: case report and review. Experimental Hematology \& Oncology 2013 2:13.

\section{Submit your next manuscript to BioMed Central and take full advantage of:}

- Convenient online submission

- Thorough peer review

- No space constraints or color figure charges

- Immediate publication on acceptance

- Inclusion in PubMed, CAS, Scopus and Google Scholar

- Research which is freely available for redistribution

Submit your manuscript at www.biomedcentral.com/submit
C BioMed Central 